\title{
Mobile Kaganga Language as Cultural Literacy and Learning Media for Elementary Schools
}

\author{
Gumono, Faculty of Education and Teacher Training, University of Bengkulu, gum.gumono@unib.ac.id, \\ ORCID: 0000-0003-2208-8376
}

Kasiyah, Computer Science Faculty, Universitas Indonesia, kasiyah@ui.ac.id ORCID: 0000-0001-63917439

Endina Putri Purwandari, Engineering Faculty, University of Bengkulu, endinaputri@unib.ac.id, ORCID: 0000-0003-2449-1740

Desi Andreswari, Engineering Faculty, University of Bengkulu, dandreswari@unib.ac.id, ORCID: 00000003-3609-4216

Sarwit Sarwono, Faculty of Education and Teacher Training, University of Bengkulu, sarwitsarwono@unib.ac.id, ORCID: 0000-0002-2424-6537

\begin{abstract}
Cultural literacy is individuals' and communities' ability to communicate within ethnic groups, countries, religions, or national traditions to preserve culture. Indonesia is rich in the diversity of regional languages as a cultural heritage. One of them is Kaganga Language as the ancestral language on Sumatra island. This paper investigates the Kaganga mobile application on the Android platform as a source of cultural literacy and learning media that supports local wisdom of regional languages in Indonesia. The application menu teaches the history of Kaganga, letters and numbers, punctuation marks, word exercises, and proverbs. Qualitative data collection involved 50 respondents in elementary schools. The feasibility testing from students said that the application was excellent in usability, effectiveness, and satisfaction. The experiments showed that the Kaganga mobile application had improved students' language skills and motivated students to learn the Kaganga language as part of cultural literacy. Furthermore, the application has been able to preserve the Kaganga language as a cultural heritage of the Indonesian nation to achieve cultural literacy skills as one of the life skills of the $21^{\text {st }}$ century. Further studies, mobile applications can be integrated with learning outcomes measurement on the e-learning website to monitor learning progress continuously
\end{abstract}

Keywords: cultural literacy, mobile learning, language skills, elementary schools

Received: 05.11.2020 $\quad$ Accepted: 14.12.2020 $\quad$ Published: 10.01.2021

\section{INTRODUCTION}

Literacy in Indonesian is still low due to the lack of awareness to make literacy a habit. Based on PISA results (OECD, 2019), Indonesia is ranked $72^{\text {nd }}$ for reading scores. This situation is a matter of concern for Indonesia because reading and understanding the lesson's meaning can obtain information, enrich experiences, learn knowledge, and develop insights. The literacy tradition is an ability to use the information to build an understanding of society's benefit. Literacy skills are more than reading and writing but include communicating in society, practices, and social relationships related to learning, language, and culture.

Literacy is an activity that humans have unconsciously carried out throughout their life. Every time they learn to receive new information and use the information to solve problems in their lives. Cultural literacy is knowledge and understanding of how beliefs, symbols, icons, celebrations, and communication from an ethnic group, country, religion, or ethnic tradition. Cultural literacy is individuals' and communities' ability to behave towards their social environment as part of culture and nation (Kemendikbud, 2017).

Indonesia is rich in regional languages' diversity as a cultural heritage. According to data from the Nation Central Statistics, there are 1,211 regional languages and their Indonesian varieties. Bengkulu people from the Rejang, Pasemah, Serawai, and Lembak districts use the Kaganga language to write various local texts. The Kaganga script is a derivative of the post-Pallava script. Ancient manuscripts in the Kaganga language as the ancestral language stored in many museums and libraries as part of Indonesia's languages' treasury. Maintaining the Kaganga language can strengthen the Indonesian nation's identity as a shaper of national character, nationality, and culture.

Mobile-Assisted Language Learning (MALL) has become a new field to assist language learning for students. This paper describes the Kaganga mobile application development as a cultural literacy 
source and learning media that supports literacy culture using local languages. The application called "Belajar Kaganga" or Learn Kaganga is built for smartphones and tablets in Android and can download for free on the Google Play Store. This activity aims to disseminate the application as a learning media for teachers and students.

Several studies have developed mobile learning as a learning resource for students. Mobile learning applications in Brazil can improve student literacy skills with the phonic method, namely, logographic, alphabetic, and orthographic (Siqueira et al., 2016). Furthermore, the blended learning application to teach Arabic alphabets effectively to students in the USA provides writing, reading, and interactive video exercises to pronounce the alphabet (AlNajdi, 2018). A learning application for local languages was also developed in Hungary, called the Mansi language originating from Western Siberia. This app provides materials and exercises to add to the Mansi language vocabulary, available in various Hungarian, Russian, and English languages (Bobály et al., 2020). Learn English with mobile learning in Czech has shown positive learning outcomes (Klimova, 2019). The development of smartphone applications for psychological autonomy in reading English in Saudi Arabia leads to increased motivation, positive behavior, and student curiosity (Alzubi et al., 2019). Students in Malaysia are also using mobile applications in Mandarin learning. It can increase the effectiveness and satisfaction of student learning (Abdullah et al., 2019). These mobile applications for language learning from various countries were proven to improve the learning process for students.

Education 4.0 requires students' ability to be creative, innovating, critical thinking, solving problems, making decisions, pro-active learning, communicating, collaborating, and working in teams/groups. Characteristics of Education 4.0 on the use of digital technology in the learning process with the cyber system so that the learning process can continuously occur without space and time limits. The advantages of mobile learning are ease of user interaction, easy access anywhere and anytime, increase learning motivation, portability, and can help students collaborate with peers (Hashemi \& Ghasemi, 2011).

The strengthening of culture in an area is determined mainly by the preservation of language in society. Learning the Kaganga language and using it in everyday life can become a cultivated action to achieve a life habit. If culture and language are not preserved, it will slowly become extinct. Preservation of language as a cultural heritage of the Indonesian nation is essential to not erode by globalization. Children as the next generation should have a national identity to love the local culture and language. The strengthening of this local culture can become an asset in their mindset, way of life, and character to build the Indonesian nation's identity amid a global society (Kemendikbud, 2017).

\section{METHODS}

This Kaganga script has (1) 28 characters consisting of 19 alphabet characters and 9 numbering characters, (2) 13 words affixes, and (3) 5 pieces of punctuation. In Kaganga, there is also the term "sandangan", which is a punctuation mark of each letter. The sight placed at the (a) top right, (b) top center, (c) top left, (d) bottom right, (e) bottom center, (f) bottom left, and (g) in front of the letter. Each sight functions to change the raw sound into a vowel, diphthong, or consonant sound. Figure 1 shows a combination of writing Kaganga characters (Sarwono et al., 2019).

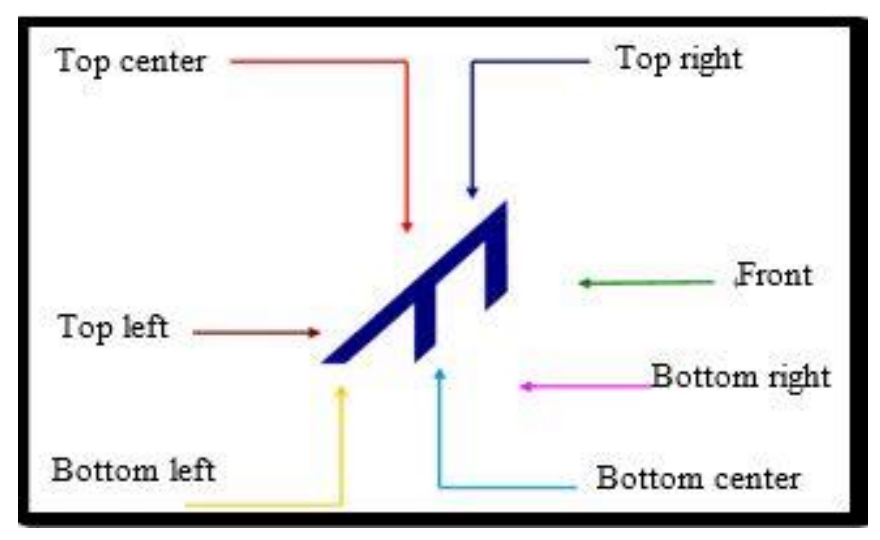

Figure 1. The rules in Kaganga writing

There are rules for writing Kaganga letters. By paying attention to the writing order rules, the appropriate form of writing will be produced, and vice versa. Writing Kaganga from an unnoticed sequence will create a different shape, thus making the letter unreadable. The following are some of the 
rules for writing the Kaganga script (Sarwono et al., 2019), namely:

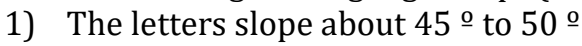

2) Write from left to right, from the bottom left corner of the upper right corner, except for letters that use a perpendicular line at the beginning or closing. The vertical line is half the height of the letter.

3) The writing of the letter Rejang has fine and rough lines. The lines drawn upwards are smooth, while the downlines are coarse or thick.

4) Each word must be spaced one or two letters from the next word.

5) Writing using the letters $\bar{E}, E, I, O$, and U must use the letter A by changing its sound.

6) Latin letters that not found in Rejang are F, V, Q X, Z. to replace it using letters:

a. $\quad$ F and $V$ used the letters $=P A$

b. $\quad$ Q used the letter $=\mathrm{KA}$

c. $\quad \mathrm{X}$ and $\mathrm{Z}$ used with the letters $=\mathrm{SA}$

Kaganga language is the original culture from Rejang district in Sumatra island, which is still preserved. One of the efforts to maintain this culture is to make it part of compulsory subjects in elementary schools. The problem is a lack of learning media availability for the Kaganga script that is attractive and easy to access. It is necessary to arrange Kaganga learning media that can display the form of letters, write letters, and be quickly disseminated. The system's data are the primary forms of the Rejang script's letters and views and the Rejang script's use in words and sentences using the Malay dialect.

The learning media tested on 50 students in fifth-grade from elementary school number 67 in Lebong District, Bengkulu province, Indonesia. This elementary school is one of the schools that has implemented Kaganga script learning as a local content lesson.

Students download the application and use their smartphones to learn Kaganga Language. The user ability achievement test aims to determine the application assessment. There is an effect on student understanding of Kaganga characters by testing the difference between two related populations. The test was carried out on the respondents in fifth-grade students to know the application impact. Respondents will run and play the Rejang script learning media application and answer questions about the Kaganga script. Before playing this application, each respondent is given a pretest and is given a posttest after playing the application. The test results show the application affects with an understanding aspect of Kaganga language.

\section{RESULTS}

\section{Mobile Kaganga Language Application}

Mobile Kaganga is designed with interactive multimedia as a language learning media. This application present material actively with music, pictures, videos, and interactive interactions. Through these facilities, students are expected to understand learning in stages according to their abilities. This mobile application is made with Unity and Adobe Illustrator software. The application user is children at school age, especially in elementary school. The program is arranged according to Sumatra's traditional patterns in background colors, font shapes, animation, music, and videos.

The application's front page (see Figure 2) displays an application icon wearing traditional clothes. The menus available are (1) history containing an explanation of the origin of Kaganga; (2) letters containing basic letter learning materials in the form of 19 alphabet characters and 9 numbering characters in Kaganga language; (3) sandangan or 13 words affixes contains material on how to change vowels from letters and how they wrote; (4) numbers containing number materials; (5) punctuation marks explain the form of punctuation marks in Kaganga grammar; (6) the word menu displays 68 essential form words commonly used in daily life; and (7) proverbs. Proverb provides enrichment for students about local wisdom and advice from ancestors taught from generation to generation about life lessons (Triyanto et al., 2020). The material provided in this menu has adjusted the extracurricular curriculum or local language content. 


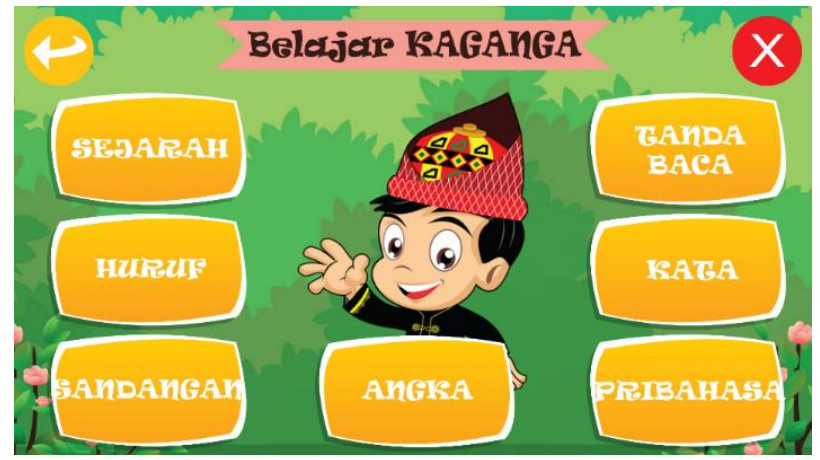

Figure 2. Main Menu of Mobile Kaganga Mobile Application

Figure 3 shows the 19 main Kaganga characters and letters when the letters menu is selected. If students want to practice reading and writing, they can choose one of letters. Then, the reading and writing menu will appear. The letter learning page aims to enable students to recognize letter shapes one by one, understand Latin forms, understand proper pronunciation, and write them. Students must write by following the application instructions. If the writing is out of the pattern determined by the system, it is considered inappropriate. If the students' have strokes successfully that passed all the tracing parts of the script, both the writing lines and the writing order, they are considered successful. Feedback is given in the form of a star with a successful sound if the answer is correct.
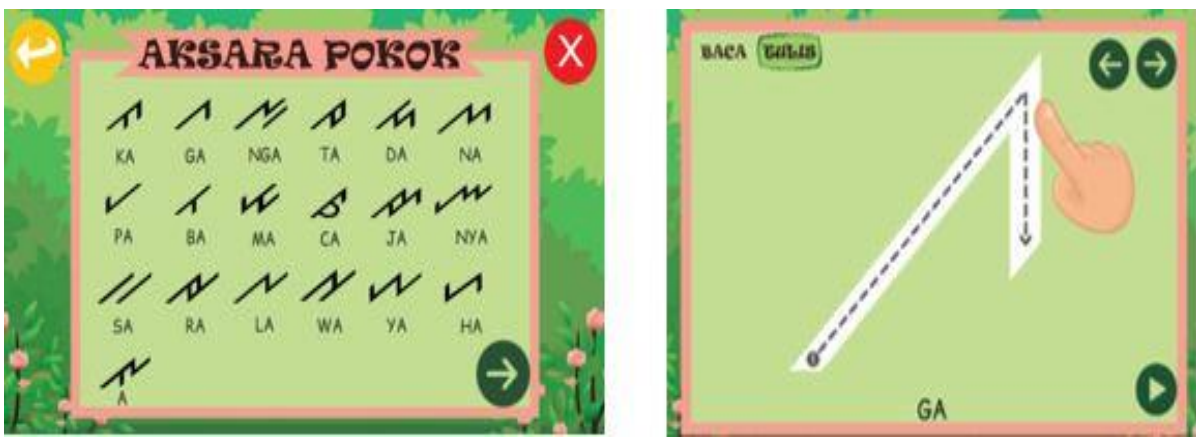

Figure 3. Learn to write and spell the letter

Figure 4 shows a menu for writing and spelling the numbers in Kaganga. Proverbs are advice from ancestors taught from generation to generation about life lessons. For example, in Kaganga "Opoi Coa Nam Idup Nak Putung Detok" or fire cannot live on a stick. This proverb's meaning is similar to doing a big job alone, and it will be difficult to achieve. But if done together and helping each other, then a goal can be achieved.
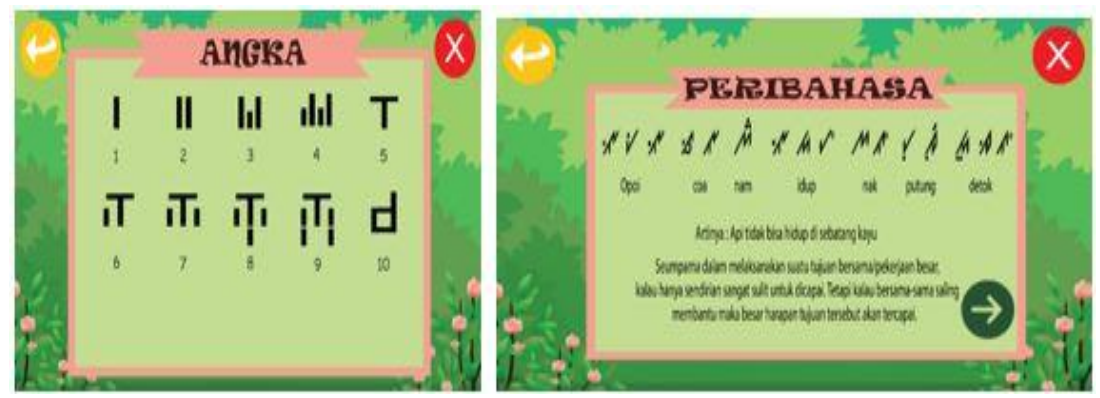

Figure 4. Learn to number and proverb from local wisdom

\section{The Feasibility Test}

The feasibility testing purposed to evaluate the Kaganga mobile application. So it can meet usability, effectiveness, and student satisfaction as program users. The system feasibility test is held to get a direct assessment from the application. The system feasibility test consists of two items about the application operating variable, five items for display items, and three application content items. The questionnaire calculation uses 4 Likert scales: very good, good, enough, and not good (see Table 1). 
Table 1. Results of Feasibility Testing for the Kaganga Mobile Application

\begin{tabular}{|c|c|c|c|c|}
\hline Indicator & $\begin{array}{l}\text { Very } \\
\text { good }\end{array}$ & Good & Enough & $\begin{array}{l}\text { Not } \\
\text { good }\end{array}$ \\
\hline \multicolumn{5}{|l|}{ Aspects of application operation } \\
\hline Open and run applications & 29 & 0 & 0 & 0 \\
\hline $\begin{array}{l}\text { Understand application functions and operating } \\
\text { instructions }\end{array}$ & 27 & 1 & 1 & 0 \\
\hline \multicolumn{5}{|l|}{ Application display aspects } \\
\hline Clarity of writing on the application & 26 & 3 & 0 & 0 \\
\hline Display clarity of reading and writing characters & 24 & 5 & 0 & 0 \\
\hline Image clarity of patterns and sound & 19 & 10 & 0 & 0 \\
\hline Color suitability of the application & 19 & 10 & 0 & 0 \\
\hline Clarity of instructions on evaluation questions & 23 & 5 & 1 & 0 \\
\hline \multicolumn{5}{|l|}{ Aspects of application contents } \\
\hline Clarity of reading and writing material & 27 & 2 & 0 & 0 \\
\hline Complete material & 28 & 1 & 0 & 0 \\
\hline Suitability of material and evaluation questions & 25 & 4 & 0 & 0 \\
\hline
\end{tabular}

Based on the feasibility results, it can be concluded that the Kaganga learning application on the operational aspect has an average value of 3.94 , with $96 \%$ of respondents said it was perfect. Furthermore, the display aspect of the application with an average questionnaire value of 3.77, with respondents saying very good in a percentage of $76 \%$. Characteristics of application content with an average of 3.91 with a ratio of $92 \%$

\section{The Learning Implementation}

The testing process uses the Learning Implementation Design on the local language extracurricular content with the Discovery Learning model. The learning process steps are carried out, namely stimulation, problem identification, collecting data, processing data, verification, and conclusions.

The learning process is carried out by dividing students into 6 groups to consist of 4-5 people. Each group uses 2-3 smartphones that have been installed with the Kaganga learning application. The application is then used in the learning process and does the assignments given according to the Discovery Learning learning model's steps.

The implementation test aims to determine the effectiveness of Kaganga material through an android application. So, the student's understanding level in learning to read and write the Kaganga can be found. The calculation of this test is by comparing the pretest and posttest data. Students were given 25 questions about the Kaganga language. The pretest given before the respondent played the learning application to read and write Kaganga characters. The posttest was given after the respondent played the learning media application to read and write the Kaganga script.

Table 2. The normality test of pretest and posttest data

\begin{tabular}{|l|l|l|l|l|l|l|l|l|}
\hline \multirow{8}{*}{} & \multicolumn{9}{|l|}{ Kolmogorov-Smirnova } & \multicolumn{2}{l|}{} & \\
\cline { 2 - 10 } & Statistic & Df & Sig. & Statistic & df & Sig. & Mean & Std. Dev \\
\hline Pretest & 187 & 50 & .000 & .880 & 50 & .000 & 52.32 & 28.37 \\
\hline Posttest & 142 & 50 & .013 & .888 & 50 & .000 & 80.80 & 17.88 \\
\hline a. Lilliefors Significance Correction
\end{tabular}

According to Table 2, the mean pretest value is 52.32, and the standard deviation is 28.37. Data mean posttest 80.80 and a standard deviation of 17.88 from a total of 50 respondents. It can be outlined that Sig. Pretest 0.000 and Sig. Posttest 0.013 , so these two data are not normal. Then the analysis will be carried out with a parametric test.

Table 3. The non-parametric test

\begin{tabular}{|l|l|}
\hline & Posttest - Pretest \\
\hline Sig. & .000 \\
\hline Mean & 28.48 \\
\hline Std. Deviation & 16.37 \\
\hline
\end{tabular}


The non-parametric test results show the Sig value about $0.00<0.05$ (see Table 3). There is a significant difference between the pretest and posttest, so there is an effect on Kaganga mobile media's use on improving students' academic abilities. Furthermore, there is a significant improvement in students' ability who learn with applications. It can be seen from the difference between the posttest and pretest scores of 28.48. The use of mobile application media can improve learning more effectively and efficiently become independent learners (Kusmaryani et al., 2019). This learning media can help students to focus and be active during the learning process. The mobile learning program has been able to help students understand, master, be involved, and apply in everyday life (Winarni et al., 2018). Learning languages using mobile applications positively impacts student values and behavior (Fryer Jr., 2013).

Language learning through the application is a new approach from previous experiences of students. Generally, language literacy learning is done by memorizing words so that students who are not good at memorizing will experience difficulties. Teaching language vocabulary shows cognitive skills by linking previously acquired knowledge. Mobile learning applications can improve students' cognitive skills, critical thinking, and intellectual abilities (Winarni \& Purwandari, 2019). Based on observations, students have high motivation and a positive attitude when learning to use applications (Indriani, 2019). Motivation is an essential aspect in the learning process to construct contextual vocabulary. This mobile application has been designed by experts and following the understanding level of students in elementary schools. Through this application, Kaganga vocabulary can be repeated many times so that new words can enter the students' long-term memory.

The learning process with the Kaganga android application provides new variations as a means of learning for students to enrich cultural literacy and technological literacy. Cultural literacy is an important thing to master in the $21^{\text {st }}$ century. Students who can accept and adapt to the Indonesian cultures become an asset for national identity. This application can be a facilitator of learning media to encourage a culture of writing and reading in Kaganga Language for students in schools.

Kaganga mobile application has been able to improve students' mastery of the Kaganga language. Students are interested in learning material through text-based and audio-based approaches in the application, complete with examples of writing and reading. Implementing learning with smartphones accompanied and supervised by the teacher can improve students' language skills (Çelik \& Yavuz, 2018; Kacetl \& Klímová, 2019). Students who learn with the Kaganga android application state that they are comfortable and convenient because they can learn anywhere and anytime. Most of them are very excited and willing to continue learning Kaganga through the application.

The aim of strengthening cultural literacy for students is to understand indigenous Indonesian culture as the national identity and enrich their ability to understand citizens' rights and obligations early (Saepudin et al., 2020). The habit of using local languages is a strategy for the cultural literacy movement. The local language is a cultural bridge to connect the family and families' identity. Local languages are a cultural heritage passed down from previous generations, with present and future generations to have a strong identity to respect and be proud of their ancestral heritage (UNESCO, 2009). It is hoped that the strengthening of national identity through regional languages will prevent the younger generation from the destructive influence of a global culture that is not following the national identity.

Further research development can build mobile applications integrated with the measurement of learning outcomes on the e-learning website so that learning progress can be monitored on an ongoing basis. It can make a strong bond on future MALL applications' pedagogic and technological aspects (Çakmak, 2019). Furthermore, challenges in developing mobile learning technologies are systems that can overcome cheating, learner distraction, and readiness (Metruk, 2020).

\section{DISCUSSION AND CONCLUSIONS}

Students can easily understand the Kaganga mobile application as a learning media to introduce Indonesian culture through the traditional Kaganga language from Sumatra island, Indonesia. The application has helped students recognize the shapes of letters and numbers, sounds, pronounce, and write. It can be seen from the value and mastery of material achieved by students where there is a significant increase from before and after using applications in learning local content in local languages.

Preservation of regional languages as the nation's cultural heritage in education can enhance the Indonesian nation's character and identity. Through this application, children can improve their ability to communicate in writing and the Kaganga language. It is hoped that this regional language preservation can unite the nation because students are taught to appreciate cultural diversity, maintenance of ethnic identity, and social tolerance. So that later, children can develop and contribute globally by maintaining Indonesian cultural identity.

Cultural literacy is one of the life skills needed in the 21st century. These skills can give birth to a 
qualified generation early and show their identity in the international world. The Kaganga application material is a program that can introduce and apply regional language skills to improve cultural literacy skills. Applications that have been tailored to the needs and conditions of students. In the future, mobile applications are expected to be integrated with the e-learning website to continuously measure learning outcomes.

\section{ACKNOWLEDGEMENTS}

This research was supported by research grant No. 2061/UN30.15/PG/2020 from the University of Bengkulu in the National Collaboration Scheme 2020.

\section{REFERENCES}

Abdullah, N. A. C., Tajuddin, A. J. A., \& Soon, G. Y. (2019). Mandarin students' perceptions of smartphone applications in Mandarin learning. Universal Journal of Educational Research, 7(A9), 61-70. https://doi.org/10.13189/ujer.2019.071608

AlNajdi, S. M. (2018). Design a Blended Learning Environment to Teach Arabic Alphabet for Non-Arabic Speaker Children Based on ASSURE Model. International Journal of Information and Education Technology, 8(2), 128-132. https://doi.org/10.18178/ijiet.2018.8.2.1021

Alzubi, A. A. F., Singh, M. K. A. P. M., \& Hazaea, A. N. (2019). Investigating reading learning strategies through smartphones on Saudi learners' psychological autonomy in reading context. International Journal of Instruction, 12(2), 99-114. https://doi.org/10.29333/iji.2019.1227a

Bobály, G., Horváth, C., \& Vincze, V. (2020). apPILcation : an Android-based Tool for Learning Mansi. 48-55.

Çakmak, F. (2019). Mobile Learning and Mobile Assisted. Language and Technology, 1(1), 30-48. https://www.researchgate.net/profile/Fidel_Cakmak/publication/332371871_Mobile_Learning_an d_Mobile_Assisted_Language_Learning_in_Focus/links/5cb07e3892851c8d22e58c8c/MobileLearning-and-Mobile-Assisted-Language-Learning-in-Focus.pdf

Çelik, Ö., \& Yavuz, F. (2018). The effect of using mobile applications on literal and contextual vocabulary instruction. International Journal of Learning and Teaching, 10(2), 126-136. https://doi.org/10.18844/ijlt.v10i2.3407

Fryer Jr., R. G. (2013). Information and Student Achievement: Evidence from a Cellular Phone Experiment. NBER Working Paper, 19113. https://doi.org/10.3386/w19113

Hashemi, M., \& Ghasemi, B. (2011). Using mobile phones in language learning/teaching. Procedia - Social and Behavioral Sciences, 15(May), 2947-2951. https://doi.org/10.1016/j.sbspro.2011.04.220

Indriani, L. (2019). EFL Learners' Attitudes toward MALL. Proceedings of the 1st International Conference on Language and Language Teaching (ICLLT) 2019, 1-7. https://doi.org/10.4108/eai.12-102019.2292211

Kacetl, J., \& Klímová, B. (2019). Use of smartphone applications in english language learning-A challenge for foreign language education. Education Sciences, 9(3), 1-9. https://doi.org/10.3390/educsci9030179

Kemendikbud. (2017). Materi Pendukung Literasi Budaya dan Kewargaan. In Kementrian Pendidikan dan Kebudayaan. Kemeterian Pendidikan dan Kebudayaan. https://doi.org/10.1017/CB09781107415324.004

Klimova, B. (2019). Impact of Mobile Learning on Students. Education Sciences, 9(2). https://doi.org/https://doi.org/10.3390/educsci9020090

Kusmaryani, W., Musthafa, B., \& Purnawarman, P. (2019). The influence of mobile applications on students' speaking skill and critical thinking in English language learning. Journal of Physics: Conference Series, 1193(1), 0-6. https://doi.org/10.1088/1742-6596/1193/1/012008

Metruk, R. (2020). Confronting the challenges of MALL: Distraction, cheating, and teacher readiness. International Journal of Emerging Technologies in Learning, 2, 4-14. https://doi.org/10.3991/ijet.v15i02.11325

OECD. (2019). PISA 2018 Results. Combined Executive Summaries. Programme for International Student Assessment (PISA) Result from PISA 2018, 53(9), 1689-1699. https://doi.org/10.1017/CB09781107415324.004

Saepudin, E., Damayani, N. A., \& Rachmawati, T. S. (2020). Cultural Literacy in Building the Character of the Community in Sindangkerta District, Tasikmalaya Regency. Library Philosophy and Practice, 1.

Sarwono, S., Yulistio, D., \& Canrhas, A. (2019). Naskah-Naskah Ulu-Islam pada Masyarakat di Provinsi Bengkulu (Ulu-Islamic Manuscripts Preserved in the Society in Bengkulu Province). 19(2), 229-242.

Siqueira, V. S. de, Cortez, P. A., Galvão, J. K. C. S., \& Rocha, M. L. (2016). ABECE: An Application for Initial 
Literacy though the Phonic Method. International Journal of E-Education, e-Business, e-Management and e-Learning, 6(2), 84-90. https://doi.org/10.17706/ijeeee.2016.6.2.84-90

Triyanto, Mujiyono, \& Sugiarto, E. (2020). Values of the authority of local art coaches as a source of learning for multicultural education. International Journal of Innovation, Creativity and Change, $11(4), 463-480$.

UNESCO. (2009). Investing in Cultural Diversity and Intercultural dialogue. In UNESCO World Report.

Winarni, E. W., \& Purwandari, E. P. (2019). The effectiveness of turtle mobile learning application for scientific literacy in elementary school. Journal of Education and E-Learning Research, 6(4). https://doi.org/10.20448/journal.509.2019.64.156.161

Winarni, E. W., Purwandari, E. P., \& Hervianti, Y. (2018). Mobile educational game for earthquake disaster preparedness in elementary school. ARPN Journal of Engineering and Applied Sciences, 13(7). 